\title{
Comentários ao Texto \\ "Gerenciamento por Sistemas ou Gerenciamento Participativo da Qualidade da Educação Brasileira"
}

Reinaldo Dias Ferraz de Souza*

\section{PREMISSAS}

Inicialmente é preciso situar a palestra do Prof. Falconi dentro de um quadro conceitual mais amplo. Esse quadro é, por excelência e pertinência, o documento do Dr. Pedro Dcmo' "Qualidade da Educação - Tentativa de definir conceitos e critérios de avaliaçäon ${ }^{n 1}$, de onde se destaca a proposta quanto às duas "dimensōes da qualidade":

- "qualidade formal: refere-sc à competência de produzir e aplicar instrumentos, tecnologias, métodos, ciência";

- "qualidade política: refere-se à competência de projetar e analisar conteúdos históricos (sociedades) pelos menos mais toleráveis (desejáveis)".

Nesse quadro, um programa de implantação de conceitos, metodologias, sistemas e técnicas de gestão da qualidade para o Setor Educação pertence à primeira dimensāo, podendo fornecer clementos importantes para o alcance da segunda.

De fato, ainda em Demo (op. cit.) tem-se que "(...) a ciência não "sabe" preferir conteúdos históricos, mas sabe instrumentar tecnologicamente a obtenção deles (...)".

\section{O CONTEXTO DE REFERÊNCIA}

O mundo atravessa os instantes iniciais de uma mudança do paradigma tecnológico industrial, correspondendo a um novo ciclo longo de Kondratiev, com profundas reper-

1 Vide Estudos em Avaliaçäo Educacional. Fundaçåo Carlos Chagas. Săo Paulo, 1990, jul-dez, n², pp. 11-22 
cussōes sobre a própria sociedade. As novas tecnologias, de produto e de processo, säo intensivas $\mathrm{cm}$ informação $\mathrm{c}$ fortemente interligadas com novos métodos de gestão, de caráter participativo, com ênfase na qualidade total e suas ferramentas (TOC, CWQC, Just-in-time, Kanban etc...).

Os novos modos de produção exigem a presença de profissionais de formação polivalente e co-responsáveis pela gestão do processo produtivo (quer se tratc da geraçăo da riqueza pela atividade industrial, quer se trate da prestação de serviço, inclusive daqueles sob responsabilidade do Estado), com profundas repercussōes sobre as políticas de recursos humanos e, mais amplamente, sobre a educação cm geral.

As modificaçöes em curso nas relaçöes capital/trabalho, bem como as relaçöes entre os agentes da cadcia fornecedores-indústria-consumidores finais, enfatizam a questão da qualidade e da produtividade e representam um enorme ambiente de mudança que permeia as estruturas produtivas e os serviços-inclusive serviços páblicos $-\operatorname{com}$ destaque especial para a Educação.

À Educaçăo cabem diversos papéis como o de prover as oportunidades de formação c capacitaçâo exigidas por uma sociedade permeada de modo cada vez mais amplo por novos pađrões tecnológicos, intensivos em conhecimento, bem como o de operar o sistema educacional com o máximo de retorno social em rclação aos investimentos realizados (dentro de um conccito próprio de produtividade).

\section{AS CARACTERÍSTICAS DE UM PROGRAMA DA QUALIDADE NA EDUCAÇÄO}

Um Programa da Qualidade para o Setor Educaçäo, conforme enfatizado em documentos do próprio MEC, deverá atender a diversos segmentos do sistema com destaque para:

- a questäo curricular;

- os instrumentos e mecanismos de apoio técnico ao processo ensino-aprendizagem;

- os "apoios didático-sociais" (merenda escolar, material escolar ctc...);

- a rede física (instalaçōes e equipamentos);

- a formaçảo, capacitação c treinamento continuado de professores e técnicos;

- o gerenciamento do sistema (gestão da escola, gestấo das unidades centrais c regionais);

- os sistemas especializados (hospitais-escola, escolas especiais, TV Educativa etc...).

Essas funçöes adequadamente agrupadas compöcm, de forma própria, os $6 \mathrm{~m}$ do Diagrama de Ishikawa, instrumentando a identificação de problemas, com base no conccito de não conformidade, em rclação aos padröes fixados pelo próprio sistema educacional em suas diferentes esferas.

Dentro da abordagem proposta pelo Prof. Falconi, o instrumental de conccitos c técnicas da Qualidade Total podem auxiliar o adequado tratamento desse universo bastante complexo. Dentre outras possibilidades destacam-se as características de algumas ferramentas: 
a) o diagrama de causa-efeito permite justapor as diversas funções e sub-funçōes do Sistema Educaçäo, correspondendo aqueles segmentos anteriormente apontados, possibilitando seu tratamento parcial conforme as prioridades do Ministério da Educação, se for o caso, sem que se perca a visão do conjunto;

b) o processo do PDCA para o gerenciamento de rotinas e melhorias pode fornecer ferramental técnico adequado ao planejamento, normalização de procedimentos, treinamento de pessoal, implantação e operaçăo de meios de verificação e retro-alimentação do sistema;

c) a metodologia de desdobramento da funçăo qualidade pode auxiliar de modo precioso a tradução de desejos, necessidades e expectativas dos "clientes" internos e externos do sistema educacional em especificação de serviços, segundo os padrōes levantados pelo Ministćrio.

Dentre os aspectos mais relevantes do método proposto destaca-se:

:- o conceito de rompimento ("breakthrough") como impōe o novo paradigma;

- a identificação de "clientes" intcrnos e externos ao sistema;

- o comprometimento da alta administraçäo;

- o conceito de "shake-down" de identificação de problemas (não conformidade);

- o caráter participativo do método;

- a descentralização dos processos;

- o binômio inovação (melhoria) e consolidaçāo (rotina).

\section{CONCLUSÃo}

Reunindo as observaçōes anteriores quantoà reorganização do mundo em um novo paradigma centrado na intensidade da informação e na conjugação de métodos de produçāo (bens e serviços) e de gestão, de caráter participativo; com a questão da produtividade do país que perde por refugo e retrabalho algo entre $20 \%$ a $40 \%$ do PIB (incluindo os serviços públicos); e com as oportunidades advindas com o Programa Brasileiro da Qualidade e Produtividade, em particular quanto à ênfase com que o Presidente da República atribui à Educação, surge como importante a estruturação de um Programa da Qualidade para o setor educacional como um todo.

Os conceitos e metodologias como os preconizados pelo Prof. Falconi aliam a simplicidade dos recursos técnicos ao papel altamente estimulante dos sistemas participativos, o que permite sua rápida multiplicaçäo por todo o sistema educacional, incluindo os sub-sistemas estaduais e municipais.

Finalmente, a instrumentaçăo técnica do Programa, nos moldes propostos, poderá ensejar o alcance daquela dimensão polf́tica, com base na indissociabilidade dos dois conceitos. 


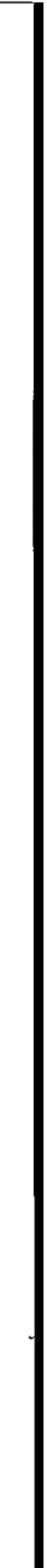

